DOI: $10.24234 /$ wisdom.v15i2.330

Olexandr RADZIVILL,

Fedir SHULZHENKO,

Ivan GOLOSNICHENKO,

Valentyna SOLOPENKO,

Yuriy PYVOVAR

\title{
INTERNATIONAL LEGAL AND PHILOSOPHICAL ASPECTS OF THE NEW PROTECTION CONCEPT OF THE COMMON HERITAGE OF MANKIND
}

\begin{abstract}
The article is devoted to systematizing the legal characteristics of objects of the common heritage of mankind; to study the philosophical and historical origins and connections of the concept of the common heritage of mankind with other legal categories and worldview systems; to determine the prospects of application of the new philosophical concept in its legal and worldview aspects. The work is based on a set of approaches united in sociological-legal consciousness, primarily historical, communicative and psychological ones, and on the methodological basis of I. Kant's philosophy. The concept of the common heritage of humanity in the context of trans-historical development of social consciousness as a critical systemmaking factor of societies of macro-level scales for the first time is investigated in the research. Mankind should return to its social consciousness an intersubjective relation to its planetary natural environment, that is, its inclusion in its multilevel diversity and recognition of its "subjectivity", if not in a legal sense, then in the awareness of its complexity, self-regulatory properties, the need for its constant cognition in feedback mode - this idea should be the main new philosophical concept of protection of the common heritage of mankind.
\end{abstract}

Keywords: protection of human rights, common heritage of mankind, international law, air and space law, sea law, philosofical worldview, legal existence.

Introduction

The concept of the common heritage of humankind was formed in international law during the 1960s and 1970s. In parallel, it touches upon the issues of a purely legal nature. First of all, the extraction of minerals out of national jurisdiction, and the issues of conservation of the world cultural and natural heritage and the protection of human rights, which have expanded the interpre- tation of the concept and through which the conception has obtained the worldview value.

Thus there is a narrow and broad interpretation of the concept of the common heritage of humankind. If one narrowly interprets only the literal definition of the objects as the common heritage of humanity in multilateral international treaties, there are only two of them: the Oceanic Lodge Area with its resources and the Moon and other celestial bodies with their resources. If, 
however, the main criterion for narrow interpretation is exclusively the international regime of the certain object and prohibition of extending national jurisdiction to it is established by the treaty, then the list of objects of the common heritage of mankind in its narrow interpretation can be supplemented by such important spaces for mankind as the open sea, open space, international airspace, and Antarctica.

Nevertheless, the most challenging issues are related to those objects of the broad interpretation of the common heritage of humankind, which, having great value for all humanity and being a subject of concern of the whole international community, can be partially or wholly within the national jurisdiction, where the state can improperly secure their protection. These include atmospheric air, biodiversity, forests, drinking water margin, cultural and natural heritage, and many other valuable objects for humanity, the protection, conservation and improvement of which require the solidarity of humankind, coordinated at all levels of collective legal existence.

The purpose of the research is to systematize the characteristics of objects of the common heritage of humankind, to study the historical origins and connections of the concept of the common heritage of humanity with other legal categories and worldview systems, to determine the prospects of application of the concept in its legal and worldview aspects.

\section{Theoretical Framework and Methods}

The work is based on a set of approaches united in sociological and legal consciousness, primarily historical, communicative and psychological ones, and on the methodological basis of I. Kant's philosophy. Accordingly, comparative and historical and sociological methods were used to the research the development of the concept of the common heritage of humanity, formal and logical and hermeneutical methods were used to analyze the practice of settlement of the issues related to objects of the common heritage of humankind. Structural, logical and comprehensive methods were used to analyze the relationships between the concept and other worldview systems.

Concerning the processed sources, their basis is the system of multilateral international acts, which determine the status and regulate the activities related to those objects of the common heritage of humanity, which are the subject of any treaty. Acts of international conferences and resolutions of the UN General Assembly on specific issues regarding the common heritage of humankind have also become an essential component.

Among the doctrinal sources are those that are directly devoted to the general and special issues of the common heritage of humanity, presented by such authors as C. J. Colombos, I. I. Lukashuk, K. Rao, G. Barberis, A. Kiss, and A. Kokka, R. Biedler, J. Tuscoz, H. O. Antselevych and others, and works of systematic and ideological nature are presented by H. Grotius, I. Kant, P. T. De Chardin, G. Reale, and D. Antiseri, H. Marcuse, I. Prigogine and I. Stengers, N. Rouland, M. Herdegen, and representatives of the Scandinavian School of Sociology.

\section{Discussion \\ Historical Origins of the Idea of the \\ Common Heritage of Mankind}

Laying the foundations of public international law in his famous work "The Right to War and Peace: Three books", Hugo Grotius (2014) in Chapter II "Of things which belong in com- 
mon to all Men" of Book II, begins his arguments that, in ancient times, all earthly wealth were perceived by peoples as their common property, and only later one began to own the land, firstly, as the property of individual powerful families and peoples, and much later - as private property. From this point of view, it follows that the idea of equal rights of all peoples to the natural resources of the planet, as their common heritage, existed in the public consciousness long before the idea of private property emerged, and therefore has a more lasting and fundamental nature.

At the beginning of modern times, the most consistent implementation of this idea became the principle of the freedom of the high seas, opposed to the attempts of Spain and Portugal to divide between the entire World Ocean and newly discovered and undiscovered land areas (Morozova, 1999, p. 806). The official wording of this principle is associated with the note of Queen Elizabeth I of England to Spanish Ambassador Mendoza (Colombos, 1967, p. 49), a little later, Hugo Grotius (2014) made its systematic substantiation (Grotius, 1916 ). The freedom of the high seas and all that is "inexhaustible as the sea and cannot be in possession of any people" is also proclaimed in Art. 9 of the "Declaration of International Law", which at the beginning of the Great French Revolution was suggested by Abbot Gregoire as an appendix to the "Declaration of Human and Citizen Rights" of 1789 (Baskin \& Feldman, 1990, p. 110). According to these ideas, in 1830, the Latin American lawyer Andres Bello established the need for a special regime of legal regulation for objects that can not be owned by any nation without harming other nations, and which should be considered as the common heritage of humanity (Colombos, 1967, p. 66). Finally, in 1898, in the work of A. de La Pradelle concerning the law of the sea appeared the very category of "the common heritage of mankind" (patrimoine commun de l'humanité), by which the French lawyer suggested to determine the special status of the World Ocean (Colombos, 1967, p. 67).

In the first half of the XX century, when geological and mining activities were intensifying in the shelf area, it was this category that was applied to minerals of sea-bed out of national jurisdictions, which nowadays represent a larger and more accessible exploitation group of objects of the common heritage of mankind within it narrow interpretation. Since the technical capabilities of the industrialized countries at that time allowed the development of sea resources only within the continental shelf, its international legal status was a particularly acute issue, the international legal solution of which was the subject of discussions during the preparation and during the work of the 1st UN Geneva Conference on the Law of the Sea. On the one hand, the doctrine of temporary "reservation" of the seabeds with their resources, for their use in the future "for the benefit of all mankind", is forming in the doctrine of international law and recommendation acts (United Nations, n.d.). On the other hand, by declaring the approach to the territories outside national jurisdictions and their resources as to the object of the common heritage of mankind, developed countries sought to freely extract minerals out of national jurisdictions.

Due to the fact that technological capabilities of developing countries generally prevented them from extracting sea-bed minerals out of their national jurisdictions, they were interested in suspending such possibility until all mining conditions were discussed and regulated by international law, taking into account interests of developing countries. Freed from colonial de- 
pendence, these countries, joining the UN, began to act with solidarity defending their own interests, among which one of the priority areas is rights to their natural resources. An important issue that they defended during the preparation and the $1^{\text {st }}$ Geneva Conference was the extension of the national jurisdiction of coastal states to the continental shelf, that is beyond the territorial waters, in order to stop the extraction of its resources without their permission.

After the Geneva Conventions of 1958 consolidated the continental shelf and its resources under the jurisdiction of coastal states (Art. 2), ${ }^{1}$ that is, they removed the grounds for considering them as the common heritage of humankind in a narrow sense, and the resources of the ocean floor are still out of national jurisdictions. The issue of their reservation for peaceful use for the benefit of all mankind has been the subject of debates since the XXII session of the UN General Assembly in 1967. In one of the resolutions, adopted at that session, was suggested to establish a Special Committee to Study the Peaceful Uses of the Sea-Bed and Ocean Floor beyond the Limits of National Jurisdiction ${ }^{2}$. In 1970, the Committee at the XXV session of the UN General Assembly adopted the "Declaration of Principles Governing the Sea-Bed and the Ocean Floor, and Subsoil Thereof, beyond the Limits of National Jurisdiction", in which the sea-bed and ocean floor area were defined by the term "international area" and its resources are proclaimed "the common heritage of mankind"3. The status of the Region and its subsoil as the common her-

1 On the Continental Shelf: Convention of the United Nations, adopted on April 29, 1958, further the Geneva Convention.

2 Resolution of the UN General Assembly, adopted on December 18, 1967, A/Res/2340(XXII), further the Resolution UN 1967.

3 Resolution of the UN General Assembly, adopted on December 17, 1970, A/Res/2749(XXV), further the Resolution UN 1970. itage of mankind was confirmed in the "Charter of the Economic Rights and Duties of States" in $1974,{ }^{4}$ which, as the Declaration on the Establishment of a New International Economic Order the same year, ${ }^{5}$ implemented, at that time, solidarity aspirations of developing countries to overcome their economic backwardness.

At the same time, the work of the $3^{\text {rd }} \mathrm{UN}$ Conference on the Law of the Sea 1973-1982 began, preparing suggestions for which the Committee on the Organization of the World in 1972 in its "General Principles" determined that new conventions on the law of the sea should come out of the concept of the common heritage of mankind. The result of nearly a decade of work at the conference was the adoption of the United Nations Convention on the Law of the Sea, 1982, where the Area and its resources were defined literally as the common heritage of mankind (Art.136) ${ }^{6}$.

Earlier, in the Agreement on the Activity of States on the Moon and Other Celestial Bodies, 1979, the objects with their resources identified in the title were literally codified, as objects of the common heritage of mankind (Art. 11) ${ }^{7}$. Division of the Moon and other celestial bodies with their resources into a separate category different from the regime of international use for outer space is connected with the prospects to start mining resources out of national jurisdictions in the near decades, is similar to the separation of the Area with its resources from the high

4 Resolution of the UN General Assembly, adopted on December 12, 1974, A/Res/3281 (XXIX), further the Resolution UN 1974.

5 Resolution of the UN General Assembly, adopted on May 1, 1974, A/RES/3201(S-VI), further the Resolution UN May 1974.

6 On the Law of the Sea: Convention of the United Nations, adopted on December 10, 1982.

7 Agreement governing the Activities of States on the Moon and Other Celestial Bodies: Resolution of the General Assembly of the United Nations, 34/681, adopted on 5 December 1979. 
sea regime into a category of the common heritage of mankind. It became a compromise between the positions of the states that considered it premature to create rules regarding the legal status of natural resources of celestial bodies and the states that insisted on it. This compromise was more pacific than pragmatic, preventing the use of the Moon and other celestial bodies for the construction of military bases and other military purposes (Cocca, 1981, p. 14). Thus, to date, only two categories of objects outside national jurisdiction are defined in international treaties literally as the common heritage of mankind: the Ocean Floor Area with its resources and the Moon and other celestial bodies with their resources.

For the broadest interpretation of the common heritage of humankind, the international law is obliged to UNESCO, which in its charter has set one of its goals - to assist the preservation, growth and dissemination of knowledge, taking care of the preservation and protection of the world cultural heritage of humanity (Art. 1, p.2) ${ }^{8}$. Two conventions adopted under the auspices of UNESCO are aimed at protecting cultural values during military conflicts ${ }^{9}$ and at comprehensively protecting the natural and cultural heritage of humanity ${ }^{10}$. As for directions for the development of the system of international legal regulation of individual components of the World Natural Heritage, one can define several special international treaties concerning: air-

8 Constitution of UNESCO, adopted on 16 November 1945.

9 For the Protection of Cultural Property in the Event of Armed Conflict with Regulations for the Execution of the Convention: Convention of the UNESCO, adopted on May 14, 1954.

10 For the protection of the world cultural and natural heritage: Convention of the UNESCO, adopted on November 16, 1972. space, ${ }^{11}$ the World Ocean, ${ }^{12}$ the Antarctic, ${ }^{13}$ certain aspects of atmospheric air protection, ${ }^{14}$ climate ${ }^{15}$ or biodiversity. ${ }^{16}$ In doctrine, resolutions of the UN General Assembly, recommendations and declarations of other international organizations, they are increasingly regarded as components of the planetary ecosystem, which is a common heritage of mankind - in its individual components and in all their interconnected diversity.

Another significant contribution of UNES$\mathrm{CO}$ to understanding the common heritage of humanity sensu lato became the Universal Declaration on the Human Genome and Human Rights adopted by UNESCO, in 1997, which defines the human genome as the common heritage of humanity, which is the basis for the primal commonality of all members of the human race and recognizing their integral dignity and diversity $^{17}$. The Declaration is aimed at overcoming racial bias, respecting the moral and ethical foundations of scientific and medical activities in the field of genetics, protecting human rights in matters of access to its achievements, and concerning social attitude to people with genetic disabilities.

Human rights in general and collective rights, in particular, are related to the ideological significance of the concept of the common herit-

11 On International Civil Aviation: Convention of the ICAO, adopted on December 7, 1944.

12 On the Law of the Sea: Convention of the United Nations, adopted on December 10, 1982.

13 The Antarctic Treaty, adopted on December 1, 1959, Washington.

14 On Long-Range Transboundary Air Pollution: Convention of the United Nations, adopted on November $13,1979$.

15 On Climate Change: Convention of the United Nations, adopted on May 9, 1992.

16 On Biological Diversity: Convention of the United Nations, adopted on June 5, 1992.

17 Universal Declaration on the Human Genome and Human Rights: Convention of the United Nations, adopted on November 11, 1997. 
age of humankind (Tuskoz, 1998, p. 178). This connection, at least in Western Europe, can be traced back to the first centuries of the modern times in the struggle of the "Protestant" nations for freedom of the high seas, demonstrating a new style of relations between the nation and its authorities, that is serving the interests of its taxpayers. In a time of discussions about the status of the sea-bed resources, where firstly were raised an issue concerning their reservation for future generations, despite their declarative nature and ambiguity of the real motives for the proclamation, humanity emerges as a trans-historical bearer of rights and responsibilities, where each generation should use and multiply the common heritage of mankind with the responsibility to the past and future generations. Further, the contractual obligations of the states enshrine their mutual intention to conduct any activity out of national jurisdictions for the benefit of all humanity, be it the high seas, the Antarctic or the outer space. As at the end of the XX century noted I. I. Lukashuk (1997), the changes that take place in the world are radically changing international law, increasingly forming it as a regulator of the activities of all humankind, causing the spread in international law of such categories as "mankind", "common heritage of mankind" and "activity for the benefit of all mankind" (p. 133).

\section{Legal Aspects of the Concept of the Common Heritage of Mankind}

Therefore, the subject of regulation of the right of the common heritage of mankind can be considered in a narrow and broad sense. Objects out of the national jurisdiction, whose status is literally defined in multilateral international treaties as a "common heritage of mankind", constitute its object sensu stricto without any cautions: it is the Moon and other celestial bodies with their resources (Art. 11), ${ }^{18}$ and the Area with its resources (Art. 136) ${ }^{19}$. Other objects can be attributed to the common heritage of humanity only sensu lato, that is, in the broad sense. But a broad interpretation requires a clarification, since it extends, firstly, to objects that, like cosmic bodies and the Area, cannot be extended to the national jurisdiction of any state, and secondly, to objects that have value for the entire humankind and the possibility to be regarded as the common heritage within national jurisdictions, in whole or in part. International law refers to the objects of the first category the following ones: international airspace, high seas, open space and the Antarctic. The second one includes a broad list of cultural and natural heritage sites, status of which is enshrined in several special international treaties, the amount of which is steadily increasing.

The legal nature of the objects of the common heritage of mankind is usually derived from the category of Roman law - res omnium communis - things common to all. The most cited list by Marcian includes air, running waters, seas and their coasts (Kofanov, 2002, Title VIII). For understandable reasons, none of those mentioned above common heritage objects of humanity in their narrow interpretation could be included in this list. Besides, Roman lawyers recognized the apparent difference in status of the certain res omnium communis, listed by Marcian. In particular, for the status of airspace, even in Roman law, there was a caution about the height of buildings that could not exceed the height of the sacral structures, the same norm was extended in

18 On the Law of the Sea: Convention of the United Nations, adopted on December 10, 1982.

19 Agreement governing the Activities of States on the Moon and Other Celestial Bodies: Resolution of the General Assembly of the United Nations, adopted on December 5, 1979, No 34/681. 
Christian and Muslim states of the Middle Ages. Controverial is also the opinion concerning the coasts: firstly, to the not yet open or undeveloped shores, Roman lawyers applied in addition to the category of res omnium communis, also the category of res nullius - a "ownerless thing", the status of which implied the possibility of capture or occupation; secondly, the understanding of the coasts of the sea as res omnium communis had a more limited interpretation than the sea itself, which status was characterized by the criterion of inexhaustibility. In particular, the right of seafarers to moor freely, replenish supplies and, if necessary, repair the vessel was not recognized by all nations. Coastal trade could also be regarded only as contractual freedom, accompanied by certain special formalities. In addition, historically fairly quickly the understanding of coasts as res omnium communis was limited by the "coastal law", which subsequently transformed into the formula "who owns both shores, owns the entire water area between them". This was primarily centred around the waters of the "closed" seas, such as the Black or the Mediterranean, but similar rules in the early Middle Ages were applied to the waters of Great Ireland during the Irish colonization of Scotland (Dillon \& Chadwick, 1967), and since the Maritime Empire of Cnut the Great, they have spread to all the British Seas and the North Atlantic (Colombos, 1967, p. 46).

By the same token, in the era of geographical discoveries and the first centuries of modern times, two maritime states, Spain and Portugal, which at this time were the first, who had started to colonize the newly discovered territories, and sought to gain control of the opposite coasts of the Atlantic and the Pacific Oceans. According to Tordesillas (1494) and Zaragoza (1529) treaties, they divided the oceans and lands "already open and those that may be open in the future" (Morozova, 1999, p. 805), fenced off to other nations of the Europe access to free use of the waters of the World Ocean and colonization of the newly discovered territories, which caused their strong opposition. A well-known statement of the King Francis I of France: "I do not remember the place in Adam's Covenant that would deprive me of a share in the possession of the New World" (Balard \& Ducellier, 1998) - is perceived as a claim to a share in the "Adamic Heritage", no matter how it was understood in that time. More specifically, the Queen Elizabeth I of England, in a note to Spanish Ambassador Mendoza stated that she cannot agree that Spain has the right to prohibit British subjects to trade or freely navigate expanses of this ocean, since the right to use the sea and airspace belongs to all (Colombos, 1967, p. 49). The Queen's note is regarded as the first age formulation of the principle of freedom of the high seas in the modern, which is taken as lex specialis in relation to the res omnium communis of Roman law - as lex generalis.

The systematic justification of the freedoms of the high seas was made by Hugo Grotius, in the work "Mare Liberum", 1609, which he wrote in connection with a dispute between Portugal and the Dutch West Indies campaign because of captured carrack "Santa Catarina" by the Dutch (Grotius, 1916). At this time, the Netherlandic Northern Provinces waged a liberation war against Spain, in the union with which was Portugal, and Hugo Grotius in his work substantiates the status of a newly formed state, relations with which should be built based on international law, and no one state or group of states cannot have exclusive rights to the legal nature of freedom of the high seas that is an international space.

The principle of freedom of the high seas 
became the legal basis on which, in the 1960s, during the preparation and operation of the I Geneva Conference on the Law of the Sea, 1958, the concept of the common heritage of mankind in its narrow interpretation was formed in international law - that is, as the common and equal rights of all peoples to spaces and their resources beyond national jurisdictions. Prior to the Conference, maritime spaces had only two modes of regulation - national and international ones. The national regime extended to inland and territorial waters, which usually did not exceed three nautical miles. Outside the three-mile zone, high seas freedoms were operating. When the need for an industrial society for oil intensified the development of the oil industry (in the Carpathian region, the Caspian, California - at the end of the XIX century), in addition to land, oil production spread to further sea-bed areas.

After the Second World War, offshore drilling became a priority area, as freedom of the high seas allowed entrepreneurs to freely build oil rigs out of the territorial jurisdiction of coastal states. Due to the prospects for the development of the World Ocean, coastal states start unilaterally extend their jurisdiction to maritime spaces beyond the limits of the three-mile zone, which provokes an adverse reaction of other states, since such actions limit the principle of freedom of the high seas not only in relation to the extraction of mineral resources but also in relation to such traditional freedoms as fishing, free navigation and flights over the high seas.

The convening of the I-st United Nations International Conference on the Law of the Sea, 1958, among other things, was aimed to the establishment of the international rules concerning the limits of extraterritorial extension of national jurisdiction to maritime spaces and to the determination of the status of the continental shelf out of the territorial jurisdiction of the states. In preparation for the conference, the Delegation of the FRG for the first time outlined the issue of extraction of subsoil out of national jurisdiction into a separate category from the high seas freedoms: it was suggested to consider the subsoil out of national jurisdictions as a "common property of all nations", the activities concerning which should be governed by a special international body, which would take into account the interests of the entire international community and work for the benefit of all mankind. Despite the declared goal "for the benefit of all mankind", the suggestions of the FRG embodied the interests of developed countries, as they were aimed at the international legal consolidation of the continental shelf status as a territory with an international regime, that is, to the legalization of already extended at that time practices for mining mineral resources in the shelf area of coastal states without their consent (Barberis, 1980, p. 648).

The Conference's preference was given to a more moderate approach followed by developing and socialist countries, which, partially, implemented the idea of reservation of mineral resources of the continental shelf for future generations, that is closed the possibility of their uncontrolled development. Three, currently in force, of the four UN Geneva Conventions on the Law of the Sea of 1958, set out the general rule of nonproliferation of limited jurisdiction of the states in the adjacent area beyond their territorial sea further the 12-mile area established from the coast (base) line (Art. 24), ${ }^{20}$ however, without establishing the standard width of the territorial sea itself; codified the customary rules governing the status of the high seas, including its four free-

20 On the Territorial Sea and the Contiguous Zone: Convention of the United Nations, adopted on April 29, 1958. 
doms (Art. 2), ${ }^{21}$ and most important, consolidated the extraterritorial jurisdiction of coastal states over the resources of their continental shelf, irrespective of the state's capacity for their development (Art. 2) $)^{22}$.

Therefore, the idea of the common heritage of humanity was not realized in the Geneva Conventions. Although substantial potential reserves of mineral resources of the ocean floor remained out of the national jurisdictions, at that time, were not available for the development. Instead, the mineral resources of the continental shelf could be reserved by the laws of coastal states under the jurisdiction of which they fell. The extraterritorial jurisdiction of the coastal states over the resources of their continental shelf created some uncertainty about its status because it did not act for the waters that covered it: the surface waters of the World Ocean, as well as the Geneva Conventions, remained either national or international, although limited to extraterritorial jurisdiction over surface waters operated within the adjacent zone for which a maximum latitude of 12 nautical miles was determined.

Active exploration of the World Ocean quickly revealed the shortcomings of the Geneva Conventions. It made it necessary to adopt a new comprehensive multilateral international treaty on the Law of the Sea that would comprehensively regulate all aspects of the exploration of the World Ocean. Such treaty became the UN Convention on the Law of the Sea, 1982, drafted and adopted at the III-rd UN Conference on the Law of the Sea. Among the most influential novels of the Convention ${ }^{23}$ : the standard (12 nautical miles) for the territorial sea was set (Art. 3) and

21 On the High Seas: Convention Convention of the United Nations, adopted on April 29, 1958.

22 On the Continental Shelf: Convention of the United Nations, adopted on April 29, 1958. Geneva.

23 On the Law of the Sea: Convention of the United Nations, adopted on December 10, 1982. the adjacent zone was extended to 24 nautical miles (Art. 33); the high seas was reserved for peaceful purposes (Art. 88), and the list of its freedoms was increased to six, at the expenses of already established freedoms (navigation, flights, laying of submarine cables and fishing), - freedom for scientific researches and freedom for construction of artificial islands and other installations (Art. 87); the continental shelf, together with the newly introduced "exclusive maritime economic zone" (Art. 55-58), relating to offshore waters have formed a separate category of extensive lengths of seas with "mixed" regime, in which over the natural resources and related issues, the extraterritorial jurisdiction of the state is preserving, while navigation, flight and laying cables issues - remain the freedoms of the high seas guaranteed by international law (Art. 7678). The Convention also defined the Arctic and the Antarctic waters regimes (Art. 234), consolidated the status of the Area with its resources (Purity XI) and defined them as a common heritage of mankind (Art. 136). Regarding the rules for exploring and extracting the resources of the Area from the signatory states, which had a real capacity to perform such activities, there were many claims for excessive bureaucratization of the process and high additional costs to the benefit of developing countries, in connection with which by the UNGA Resolution of June 28, 1994, was adopted the "Agreement relating to the implementation of Part XI of the United Nations Convention on the Law of the Sea of December 10, 1982", ${ }^{24}$ which greatly simplified all formalities related to activities in the Area.

Thus, only in the UN Convention of 1982, its legal implementation found an approach, which was verbalized during preparation to the I

24 Agreement relating to the Implementation of Part XI of the United Nations Convention on the Law of the Sea: United Nations, adopted on December 10, 1982. 
UN Conference on the Law of the Sea of 1958: the specificity of the territories referred to the common heritage of humanity in its narrow interpretation, consists in that these territories cannot be appropriated by any state or, moreover, by a private individual, whereas the resources extracted from their subsoils are the object of appropriation, on the terms stated by the agreed will of the states, which have agreed to compulsoriness of appropriate international treaties. The UN Convention of 1982 also identified a lot of other aspects of the development of the World Ocean, activities in which are made for the benefit of all humanity, reconciling national interests for each category of the sea expanses with interests of the entire international community.

By analogy with maritime law, in which the concept of the common heritage of mankind in its narrow interpretation and the separation of its objects from the high seas regime took a relatively long time, in space law, which developed rapidly in the 1960-1970s, also took place a delimitation of the mode of activities of states in outer space from the mode of activities on the Moon and other celestial bodies, which, in the future, were taken as territories of mineral resources extraction. It should be noted that The Agreement Governing the Activities of States on the Moon and Other Celestial Bodies, 1979, in which planets (except the Earth) and their resources are defined as a common heritage of mankind in its narrow interpretation (Art. 11), ${ }^{25}$ was taken in the atmosphere of heightened enthusiasm concerning the prospects for the concept of the common heritage of mankind and in general the abilities of the international community to act solidary. At the time, some authors even suggested

\footnotetext{
25 Agreement governing the Activities of States on the Moon and Other Celestial Bodies: Resolution of the General Assembly of the United Nations, adopted on 5 December 1979, No. 34/681.
}

recognizing the principle of the common heritage of mankind as one of the fundamental principles of the international law (Rao, 1981, p. 275), referring in particular to the Declaration on Principles, 1970, which, for the first time, defined the principles of the UN Charter as "basic principles of the international law" (para. 3$)^{26}$. The preamble to the Declaration indeed contains a reference of the UN General Assembly to the principle according to which the outer space, including the Moon and other celestial bodies, is not subject to national appropriation either by proclaiming sovereignty over it, or by their use or occupancy, or by any other means.

The mentioned principle was firstly proclaimed in the Declaration on the Peaceful Uses of Outer Space, 1963, and enshrined in the Outer Space Treaty, $1967^{27}$. However, unlike the seven fundamental principles of international law recognized at that time, the principle of the common heritage of humankind cannot be removed from the UN Charter. Besides, the Agreement on the Moon and other celestial bodies, in which their status as a common heritage of humanity is enshrined, today is recognized as obligatory one only by fourteen states, which does not give grounds to consider it as a norm of Article 11, whereas the Outer Space Treaty, 1967, where the universal obligation of the states to act for the benefit of entire mankind and the basic principles of such activities are enshrined, rubs to 100 member states.

It is also necessary to dwell separately on the particular mode of the orbit of geostationary

26 On Principles of International Law Friendly Relations and Co-Operation Among States in Accordance With the Charter of the United Nations: Convention of the United Nations, adopted on October 10, 1970.

27 Treaty on Principles Governing the Activities of States in the Exploration and Use of Outer Space, including the Moon and Other Celestial Bodies: Resolution of the United Nations, adopted on January 27, 1967, RES2222/XXI. 
satellites allocated within outer space. In addition to the basic principles of activities in outer space, according to the Charter of the International Telecommunication Union, the members of the Union shall take into account that radio frequencies and the orbit of geostationary satellites are scarce natural resources that should be used rationally, efficiently and economically, in accordance with the regulations of the Radio Regulations to ensure equitable access to this orbit and these frequencies by different countries or groups of countries, taking into account the particular needs of developing countries and the geographical location of some countries (Art. 44, 196. 2.11) ${ }^{28}$. The requirements of the International Telecommunication Union Convention are met by the Radiocommunication Bureau and its Head (Art. 12, 177 a). It should be noted separately that in the Charter and the Convention is enshrined the right of everyone to equal conditions of access to international telecommunication networks (Art. 33,179 ), including a number of special provisions concerning dedicated lines and frequencies, operational messages and other specifically agreed and restricted cases of concession of priority. Based on these regulations, I. I. Lukashuk also refers to international power grids to the common heritage of humanity in its broad interpretation (Lukashuk, 1997, p. 134).

Consequently, the activities of the states in international airspace, outer space, the World Ocean waters and the Antarctic are enshrined in system-making multilateral international treaties, the typical set of principles of which can differ only by the degree of a concretization in a treaty, and the principal of which is the duty of the states to act within these territories solely for the peaceful purposes and for the benefit of en-

28 Constitution of the International Telecommunication Union, adopted on December 22, 1992. tire humanity and to refrain from any claims to the extension of national jurisdiction to the said international territories.

In this regard, one should follow the evolution of views of the Antarctic, after the discovery of which in 1820 , concerned states sought to divide it. These aspirations were first expressed at the Seventh International Geographical Congress in Berlin in 1899 by the representative of Great Britain, R. K. Markham (Shchiptsov \& Iefremov, 1997, p. 30) and suspended only with the adoption of the Antarctic Treaty, 1959 (para. 2. Art. IV), ${ }^{29}$ which was further confirmed by the Madrid Protocol, 1991 to the Antarctic Treaty (Art. 4) ${ }^{30}$ and strengthened by the prohibition of the activities connected with mineral resources mining (Art. 7). Due to the obligation of the states not to extend their jurisdiction to the Antarctic, and most importantly to the systematic impact of this part of the Planet on its global ecosystem, it is regarded as a common heritage of mankind in a number of the UN GA Resolutions (Antselevich \& Radzivill, 1997) and a long list of publications (Lukashuk, 1997, p. 135). Although literally its status has not been defined in such terms, the main reason for the annexation of the Antarctic to the objects of the common heritage of humanity is the awareness of its importance for the Planet's life, that is why the parties determine the Antarctic's status as an international nature reserve designated for peace and science (Art. 2).

As for the airspace, its division into two regimes - national and international - was indirectly initiated by the Paris Convention on the Regulation of Aerial Navigation on October 13, 1919. It entrenched the sovereignty of the states over

29 The Antarctic Treaty, adopted on December 1, 1959, Washington.

30 On Environmental Protection to the Antarctic Treaty: Protocol, adopted on October 4, 1991. 
their airspace (Radzivill, Pyvovar, Sopilko, \& Pyvovar, 2018, p. 281). The same rule was enshrined in the Chicago Convention on International Civil Aviation on December 7, 1944 (Art. $1)^{31}$. The status of international airspace is directly defined in the maritime law conventions as one of the freedoms of the high seas, namely the freedom of flight. It is the Geneva Convention on the High Seas (Art. 2) ${ }^{32}$ and the United Nations Convention on the Law of the Sea (Art. 87), where such freedom is still preserved over the exclusive maritime economic zone (Art. 58) ${ }^{33}$.

The regulation of relations on the use of airspace for some time did not touch on the issues of protection against air pollution, which became the subject of special attention as an object of the common heritage of humankind sensu lato - after the Stockholm Conference of 1972, from which in international law has been developing an integrated approach to sustainable development and environmental issues in all its components. In particular, while developing "Principles of Cooperation between States in the Field of Impact on the Weather" in 1980 by experts of UNEP and WMO, the first principle was suggested to be defined as follows: "The Earth's atmosphere is a part of the common heritage of mankind"34. In the works of some international lawyers, it is also suggested to consider the atmosphere as the common heritage of humanity, and the atmospheric air as a particularly valuable natural resource, the loss of primary qualities of which will have the most catastrophic conse-

31 On International Civil Aviation: Convention of the ICAO, adopted on December 7, 1944.

32 On the High Seas: Convention Convention of the United Nations, adopted on April 29, 1958.

33 On the Law of the Sea: Convention of the United Nations, adopted on December 10, 1982.

34 Review of the impact of production and use of energy on the environment: report of the Executive Director: United Nations, adopted on January 2, 1976. (UNEP/GC/61). quences for humanity. As, in particular, A. Kiss notes as a critical component of the environment, the atmosphere belongs to all humanity, it is part of the common heritage of humankind (Kiss, 1983, p. 102). The atmosphere is the natural resource partly under the jurisdiction of the states, activities of which can affect the quality of the air, however, remains an indisputable fact. Several bilateral international treaties and arbitration and court decisions in states' disputes regarding air pollution have been known since the Trail Smelter case (1938) (Herdegen, 2013, p. 394). In 1979, under the auspices of the European Commission ECOSOC one adopted the Convention on Long-range Transboundary Air Pollution at a regional level, which in particular provided monitoring mechanisms for the implementation of the "Cooperative programme for monitoring and evaluation of the long-range transmission of air pollutants in Europe", which should act based on standardized monitoring procedures, taking into account existing national and international programs, in particular by involving national observation stations (Art. 9). ${ }^{35}$

After all, the international community is increasingly aware that the common heritage of humankind is the entire ecosystem of the Planet in multilevel diversity and multi-inertial dynamics of its components (Bidler, 1976, p. 71). In this sense, for example, in the United Nations Framework Convention on Climate Change, the Parties recognize that climate change and its adverse effects are a matter of common concern for mankind, ${ }^{36}$ and in the Convention on Biological Diversity, in the preamble, the Parties understand the genetic, social, economic, scientific, educa-

35 On Long-Range Transboundary Air Pollution: Convention of the United Nations, adopted on November 13, 1979.

36 On Climate Change: Convention of the United Nations, adopted on May 9, 1992. 
tional, cultural, recreational and aesthetic value of biodiversity and its importance for the evolution and life of biosphere systems, confirm that conservation activities are a common concern of all humankind ${ }^{37}$. These and other special conventions on the protection of individual components of the Planet's ecosystem contain numerous references to the UNGA resolutions, final acts of international conferences, and international treaties on specific environmental issues.

They also affirm the sovereign rights of the states over their resources and their development activities, as well as the fact that some states' standards may be incompatible and unsubstantiated in terms of economic and social costs of other states and general environmental issues, and that states are responsible for ensuring the safety activities within their jurisdiction or control, which would not harm the environment of other states or areas out of the national jurisdiction. ${ }^{38}$

The success of regulating the protection of objects of the common heritage of mankind within national jurisdictions is primarily caused by the effectiveness of procedural mechanisms. For the first time, such mechanisms were established in the Convention for the Protection of Cultural Property in the Event of Armed Conflict (1954), which states in the preamble that the High Contracting Parties have accepted this Convention being convinced that the damage to the cultural property belonging to any people irrespective of the damage to the cultural heritage of all humanity since each people makes its contribution to world culture and considering that the preservation of cultural heritage is of great

37 On Biological Diversity: Convention of the United Nations, adopted on June 5, 1992.

38 Vienna Convention for the Protection of the Ozone Layer: Convention of the United Nations, adopted on March 22, 1985. importance to all peoples of the world and that it is important to ensure the international protection of that heritage $\mathrm{e}^{39}$. A detailed system for the conciliation of the interests of individual countries with the interests of all mankind in the issues concerning the protection of the common heritage of mankind sensu lato is implemented in the UNESCO Convention concerning the Protection of World Cultural and Natural Heritage, adopted in 1972 at United Nations General Conference on Education, Science and Culture held in Paris. Its preamble states, in particular: "considering that deterioration or disappearance of any item of the cultural or natural heritage constitutes a harmful impoverishment of the heritage of all the nations of the world; considering that parts of the cultural or natural heritage are of outstanding interest and therefore need to be preserved as part of the world heritage of humankind as a whole,... adopted this Convention". 40 In the Convention, the cultural and natural heritage and criteria for the attribution of objects within the jurisdiction of the states to its monuments that need protection are defined. At the same time, the categories and subcategories of such objects are established, as well as the procedures for determining, identifying and recording them in appropriate registries are enshrined together with general and special privileges for financial support for countries in which the monuments are located. The idea of preserving the World Cultural Heritage found its continuation in the conception of a global information civil society, declared in the Okinawa Charter

39 For the Protection of Cultural Property in the Event of Armed Conflict with Regulations for the Execution of the Convention: Convention of the UNESCO, adopted on May 14, 1954.

40 For the Protection of the World Cultural and Natural Heritage: Convention of the UNESCO, adopted on November 16, 1972. 
$(2000)^{41}$ and in more details disclosed in the Declaration of Principles "Building the Information Society - A Global Challenge in the New Millennium", 2003, in which, in particular, is stated that: "Cultural heritage is one of the most important elements of the identity and consciousness of people who connect society with its past. The information society should, by all appropriate means, including digitization, collect and preserve cultural heritage for future generations (para. 54) ${ }^{42}$.

Therefore, the general process of international legal protection of objects of the common heritage of mankind in its broad interpretation seems to be inductive, rising from fragmentary generalizations and relevant principles and rules of legal protection of its individual objects - to a universal systematic approach, the purpose of which can be achieved by defining, on the basis of scientifically grounded complex researches, indicative list and structure on different categories of significance of objects of the common heritage of mankind, on the basis of which one should further develop the procedural issues of their protection, taking into account, firstly, their characteristics, first of all, the exhaustiveness and the ability to recover, and secondly, the jurisdictional belonging. The adoption of a broad interpretation of the common heritage of mankind as a general principle and, in the future, the relevant erga omnes rule, keeps the conventional principle of non-extension of national jurisdiction within the international territories as a defining legal criterion for distinguishing regimes of exclusively international legal regulation of objects out of national jurisdiction and objects

41 Okinawa Charter on Global Information Societ, adopted on July, 21-23, 2000.

42 Declaration of Principles Building the Information Society:. a global challenge in the new Millennium, adopted on December 12, 2003. WSIS-03/GENEVA/DOC/4-E. within national jurisdictions. Each category of the latter requires specific international legal standards and procedures for the conciliation of the national interests with entire mankind.

\section{Worldview Aspects of the Concept of the Common Heritage of Mankind}

The humankind has got as the common heritage the best of all worlds: it is a conviction of G. W. Leibniz, as the emotional basis of the creative inspiration of modern times, is sincerely shared by the part of humanity that loves and seeks to preserve this world and prevent its destruction by improvident exploitation and negligence. The implementation of this conviction at the level of the worldview system became the concept of the noosphere, which is understood as the "youngest one" of the Planet's geospheres, ordered by the constructive activities of humankind. Formulated at the beginning of the XX century in the works of E. Leroy, V. I. Vernadskyi and P.T. de Chardin, it has become a powerful worldview project aimed at making the common cause of humanity. Sequentially, it inherited and developed the ideas of I. Kant, concerning global civil society (Radzivill \& Pyvovar, 2019, p. 40), in which mankind emerges as a collective subject that has been moving throughout the entire historical period to the organization of such state of social relations, in which, human abilities are laid down by nature, and will get the best opportunities for their implementation and development (Kant, 1784). It should be emphasized that I. Kant contrasts these humanistic abilities with the biological instincts of a human, the conscious control over which are devoted his three famous "critiques" and many other works (Reale \& Anticery, 2003, p. 629). Three levels of legal existence that need special attention in the 
legal support of the project of global civil society are the state public order within the nation, which should be republican; international law, which should be based on the federalism of sovereign states, limited only by the conditions of mutual hospitality and the observance of rules of international law within relations with each, and a person who should be considered as a full-fledged subject of global civil law and order (Kant, 1795).

The formation of the more significant part of the common heritage of mankind occurred before its appearance, in the process of evolution of the Planet. According to P. Teilhard de Chardin, one of the authors of the concept of the noosphere, Earth Mother, most effectively among other planets, has directed the time given for her development, having done a tremendous amount of work to form and improve the means of ensuring the homeostasis of the Planet and creating the preconditions for the appearance of Homo sapiens, who has the most effective opportunities to ensure his/her further crisis-free development in the noosphere - the environment of harmonious coexistence of nature and human (Teilhard de Chardin, 1955, p. 119).

On the other hand, the irresponsible exploitation of nature or achievements of other human beings by a human is also a kind of "heritage" defined by I. Prigogine as the "curse of living systems", the essence of which is reduced to the fate of the biological system to maintain its own orderliness, destroying the orderliness of other biological systems (Prigogine \& Stengers, 1986, p. 271). Uncontrolled by the cultural heritage in its broadest interpretation, the primordial biological instinct - to kill to get meat and animal skin, transformed into the practice of cattle grazing to the desertification of steppes or burning out of forests for agriculture purposes - have not chan- ged to this day and only acquired a global scale throughout the "Industrial age". It would seem that actions under the influence of biological instincts familiar to a primitive human being, who has been continuously teetering on the brink of survival, should be qualified as abnormal to the human of the XXI century, endowed with powerful technological capabilities and knowledgeable about information, in particular regarding the consequences of his/her improvident activities. However, the modern world is now in such a deep crisis that the level of spiritual and intellectual characteristics of a large number of inhabitants of the Planet does not exceed the level of a cannibal Neanderthal. The belief in "progress by itself", typical for both Western and Westernized non-Western societies, has left hard work on sustaining and reproducing a cultural level of each of the next generations of humankind, which is a major safeguard against the rise of social entropy, as a criterion of uncertainty and chaos. Instead, the gap of insufficient cultural education is filled by obtrusive and increasingly "anti-cultural" advertising and other forms of "information noise" that can only affect the minds of the poorly educated human. Perhaps the most powerful marginalization of the population of the Planet, occurring at the turn of the XX-XXI centuries, by avalanche-type frees the spontaneous component of human nature, which, ignoring the common collective interests of different levels and rational rules of maintaining their orderliness, directs it to the realization of the exclusively individual needs, which under the influence of advertising industry, are rapidly growing far beyond common sense (Marcuse, 1964, X). Care about its natural or social environment and sense of responsibility for something that is not formally provided with appropriate sanctions seems incomprehensible and meaningless aor the one- 
dimensional worldview of the "ideal consumer".

The drawbacks of the worldview basis of the average modern person, as extremely individualistic and at the same time substantially standardized through the simplification of personal motivations, are, perhaps, the most clearly manifested through property relations. For example, exploring the relationship of individuals in territorial communities to their shared property, the Scandinavian sociologist E. Gulbrandsen concludes that, without being restricted by any special quotas, community members seek to use common property, which is an limited community resource of the community, with the greatest personal profit, which results in excessive exhaustion or complete destruction of this property (Larsen, 2004, p. 206). As the author rightly considers, the way out cannot be limited only by the setting of quotas, and although this is of great technical and legal importance, the main problem is the excessive aspiration for getting a "free" profit, which initially covers certain individuals, and then, as a rule, the entire community. Despite the awareness of the negative effects of the "cumulative effect" of such actions, people convince themselves that "they still do the same", that is, choose from two alternatives, the variant of individual behaviour that, including other similar ones, leads to a predictable crisis (Larsen, 2004, p. 215).

The mentioned considerations can also be applied to the problems related to the common heritage of mankind in its broad interpretation. The institute of collective property of different levels as a "technical and legal dimension" of relations concerning the use, protection and multiplication of objects of the common heritage of humanity has a long-standing practice of legal regulation. However, the interpretation and success of this practice are caused by the philosoph- ical and legal basis on which will rely the parties of the legal relation concerning its individual objects. Tracing the historical origin of power and property, Hugo Grotius (2014) concludes that when in ancient times everything was collectively owned and indivisibly common, forming common wealth, such a state of things was provided by two conditions: great simplicity and great mutual sympathy of people, who were then free from vicious habits, defects and crime, because they did not know the enslavement and punishment. The belief of Grotius is confirmed by current studies in legal anthropology, the subject of which is connections between legal phenomena and the constants of human nature. In particular, N. Rouland, describing the quasi-legal ideas about the features of inheritance in societies with the tribal system, shows their conditionality by the worldview, the basis of which is the awareness of the organic unity of the genus and tribe with their habitat, which is their collective heritage, which, under the certain rules, can serve as an inexhaustible source of the resources necessary for life (Rulan, 2000, p. 52). The rights and duties of the tribe concerning its collective heritage derived from its relation to time in general and inheritance, in particular. In Western society, a testator and an heir are considered as separate successive elements of the movement of property in time, meanwhile, in traditional society, the property remains chronologically statical, not changing its collective affiliation: takes place only a change in the generations that realize themselves not as beneficiaries but as responsible users for preserving the common heritage. However, in traditional societies, where the concept of absolute property is absent, the disposal of collective property and its individual components is a rather multi-level process. As a matter of necessity to maintain in good order and pass on the 
heritage of the society from the previous generations to the next ones, the inheritance order is closely connected with the structural organization of the society. It is formed on the basis of both the specifics and functions of the property itself, as well as powers and responsibilities of particular age and gender groups or individuals established by a tradition. Accordingly, certain categories of things can remain collective, and some can be in possession of particular families, others belong to separate groups of individuals. The critical point is that the sacrality (that is, the special value) of some things does not allow them to apply such dominant forms in the "onedimensional" worldview of modern societies motion modes of things as purchase and sale or foreclosure (Rulan, 2000, p. 76). Instead, some of them can be won or granted, or be a subject of reward or gratitude. As N. Rouland notes, traditional societies do not entirely ignore the individual, but they integrate him/her into a community project. The differences concern more levels than the inheritance nature (Rulan, 2000, p. 115).

Thus, the state of social consciousness is also a product of a historical process, which, in addition to the advancing component, is complicated by fluctuations, under the influence of different scales and contradictory constants of different dimensions of human nature. If we trace back the development of the social consciousness of humanity transhistorical, generally, there are three major stages in it, the sequence of which forms a known dialectical triad (thesis antithesis - synthesis) (Radzivill, 2017, pp. 6667). During the first and the greater part of history (from the Upper Paleolithic Age to the Neolithic Age), when the species Homo sapiens for about 50 thousand years slowly separated themselves from their "maternal" natural environment as a "child system", settling all genera within the territory of the Planet for life, formed over this long period the traditional family law was based on stable, fixed at deep psychophysical levels harmony of maternal and paternal natural law, representing itself a system of well-adjusted rules, which maximally thoroughly provided the regulation of tribal and intergenerational relations and human relations with nature.

The second half of history, covering about 12 thousand years including the Neolithic revolution and its continuation in the era of "diffusion" of civilization, is the antithesis to the first half, deforming its worldview foundations by processes such as: a) transition from appropriative to reproductive ways of economic management that continued in social division of labor in professional corporatization and caste organization of societies - building regional civilizations; b) transition to organization of population according to the territorial principle (from stationary communities of Neolithic farmers to communities of city-states and semi-barbaric "world states-empires" regional civilizations); c) conflict between maternal and paternal law, which led to the dehumanization of social relations through the legitimization, sacralization and institutionalization of property, exploitation of a human by a human, and establishment of religious and legal systems that justify violence and the rule of the ruling classes. Thus, during the second half of history, on the basis of the advancement in technologies and in scales of organization of considerable human groups, appear elements of degradation of social consciousness, especially in the loss by a personal sense of unity and harmony with his/her social and natural environment. Public relations, typical for this period societies, are subjected to the rigid requirements of integration of population, territories, and resources, and provided with political and ideological violence 
characterized by T. Hobbes as "the war of all against all" - referring to the attitude of man to his kind and his nature.

According to the "law of the negation of the negation", two unequal halves of history, correlating to each other as "thesis" and "antithesis" of the dialectical triad should end in the third stage - "synthesis", at which out of the social relations and public consciousness should be eliminated those features of the second half of history, which are responsible for their dehumanization, and the best achievements of mankind of both halves of history should be agreed by a certain compromise, making the common heritage of mankind. The transition to this, in the long term, the crisis-free and long-term stage is obviously connected with the new age, which itself is characterized by anxiety and internal contradiction. Western Christian society of modern times, being in a state of constant discoveries and changes, builds, under their influence, new ideological orientations, complicating this generally continuous process with different-scale fluctuations through the eclectic combination of new ideas in individual and collective worldview with inertness of old values (Marcuse, 1964, p. 51). The major, already conscious, ideological changes of this period consist in the formation of consciousness of civil society, which should replace the remnants of the consciousness of caste societies that during the last millennia has been dominated in societies - building regional civilizations. Nevertheless, in the psychological or human dimension, it is a change of the "subject-object" attitude of a human to his/her social and natural environment to the "intersubjective" nature of social relations, which should be based on a sincere, informal mutual recognition of equal legal existence of its participants.

It is the philosophy of I. Kant, based on knowledge of the features of human consciousness and the priority of self-reflection in the formation of any judgments of a theoretical or practical nature (Kant, 1781, p. 32), has become the systemic world-view of the "intersubjective style" of communication. If the Cartesian methodology, still is built on the "subject-object" relations of the researcher to the natural or social environment, allows their analysis on the basis of subjective, uncontrolled by the reflection researcher's ideas, which leads to the destruction of existing in reality complex interconnections, the Kantian approach makes the researcher involved in these relationships in a mode of constant interaction with objective reality. In this approach, reviewing and updating a researcher's previous ideas or policies becomes an integral part of his/her work, a condition for its success and adequacy.

As a collective heir of Planet Earth, humankind vested with the power of geological processes and the ability to think and coordinate its collective actions should also build its relations with the Planet as an integral part of it, considering its responsibility not only to past and future generations of its species but also to its Planet in general and the components of its global ecosystem. Only in this mode, one should follow the principle of the Hippocratic Oath "First do no harm!". No matter how negatively it is perceived from the point of view of the materialistic (also subject-object) approach, but only by starting to treat our Planet and the most important phenomena of multilevel diversity of all its components as empowered with a particular subjectivity, humankind will be able to drive from "the deadlock" of formal approach the whole system of legal and organizational protection of the environment and human rights that continue to be violated, despite the titanic efforts of the better 
part of humankind in this direction.

Therefore, the concept of the common heritage of humankind is part of a set of worldview improvements of modern times, the subject of which is the legal issues of the use, preservation and multiplication of the most important for human values of anthropogenic and natural origin. Other current legal components of these changes, closely related to the concept of the common heritage of humanity, are the concept of sustainable development, the acquis communautaire of the European Union (Prudchenko, 2007), the concept of the "human dimension" of the OSCE (2011). The latter, aimed at humanizing the activities of power structures through the recommendation acts, embodies formulated in the late XVIII century categorical imperative of I. Kant (1781): "Act in such a way that you treat humanity, whether in your person or in the person of any other, never merely as a means to an end, but always at the same time as an end" (p. 657), which can only be realized and embodied by a person in a state of freedom.

\section{Conclusions}

The conducted research and its conclusions allow us to distinguish as a general direction in the complex of multifaceted and different-scale worldview improvements of modern times - the change and displacement of the "subject-object" style of communication of a human with her social and natural environment, i.e. the "intersubjective" style that involves recognizing the "legal existence" of the other side of communication, even when it is neither thinking nor alive but needs protection based on the understanding of all the complexities of its nature: in the mode of constant feedback with the actions of the active thinking subject, which is mankind, and readi- ness to stop or change these actions in the case of negative response.

Stages and integral components of this general direction were, in particular, the works of Hugo Grotius on the foundations of international law - an important systematic factor for modern humanity, ideas of I. Kant concerning the conditions for the development of world civil society, as well as his whole system of philosophy, which made a human as a centre of any theoretical and practical activities, and the need to constantly be aware of the conditionality of human consciousness - a methodological and ideological basis for an intersubjective style of communication. Regarding the ideas of Kant, the concept of the noosphere, considering a human as the centre of the Universe, and reasonable humankind as a system making geological force, which can keep the planetary environment in the best possible state employing rational, constructive activities. Derived from it the anthropic principle, the concept of the human dimension of the OSCE, the concept of the common heritage of humanity in international law specify the general movement for the humanization of human activities, after several thousand years of its dehumanization, brought to a critical state in industrial society.

For the concept of the common heritage of mankind, its specific characteristic is that in resonance with contemporary philosophical ideas, many of its components and practice of application have a direct output or a significant connection with legal categories and procedures, which allows it to be used to create a new worldview system of "social engineering", or practical sociology and jurisprudence, the subject of research and regulation of which will be the phenomena of natural and anthropogenic origin that are of considerable value for all mankind and should be saved for its future generations. 
In order for humankind not to become a threat to its common natural and cultural heritage, worldview changes of the New Age should, after all, reach their specific level: the mankind should return to its social consciousness an intersubjective relation to its planetary natural environment, that is, its inclusion in its multilevel diversity and recognition of its "subjectivity", if not in a legal sense, then in the awareness of its complexity, self-regulatory properties, the need for its constant cognition in feedback mode.

\section{REFERENCES}

Antselevich, G. A., \& Radzivill, A. A. (1997). Razvitie pravovykh voprosov (The Development of Antarctic Legal Issues by the UN General Assembly Resolutions, in Russian). In Antarktika: istoriya, sovremennost, perspektivy (Antarctica: history, modernity, prospects, in Russian) (pp. 102-119). Kyiv: Naukova dumka.

Balard, M., \& Ducellier, A. (1998). Le partage du monde: échanges et colonisation dans la Méditerranée médiévale. Paris: Publications de la Sorbonne.

Barberis, J. A. (1980). Los recursos naturales compartidos entre estados et el derecho internasoinal. Revue internationale de droit comparé, 32(3), 648-649.

Baskin, Iu. Ia., \& Feldman, D. I. (1990). Istoria mezhdunarodnogo prava (History of International Law, in Russian). Moscow: Mezhdunarodnyie otnosheniya.

Bidler, R. B. (1976). The Settlement of International Evironmental Disputes. In Wisconsin Sea Grant College Program, Technical Report 231. Madison: University of Wisconsin University.
Cocca, A. A. (1981). The Advances in International Law. Through the Law of Outer Space. Journal of Space Law, 9(1), 1321.

Colombos, C. J. (1967). The International Law of the Sea ( $6^{\text {th }}$ rev. ed.). London: London Longmans.

Dillon, M., \& Chadwick, N. (1967). The Celtic Realms (History and Civilisation). London: Weidenfeld \& Nicholson; N.Y.: New American Library.

Grotius, H. (1916). The Freedom of the Seas. New York, Oxford University Press, American Branch. Retrieved March 31, 2020 from: https://archive.org/details/freedomofseasorr1916grot/page/n5/mo de/2up.

Grotius, H. (2014). The Rights of War and Peace. Indianapolis: Liberty Fund. Retrieved March 31, 2020 from: https://oll.libertyfund.org/pages/grotius-warpeace.

Herdegen, M. (2013). Principles of International Economic Law. Oxford: Oxford University Press. https://doi.org/10.1017/S0165070X12001362.

Kant, I. (1781). Critique of pure reason (P. Guyer \& A. D. Wood, Trans. and Ed.). Cambridge: Cambridge University Press. Retrieved March 31, 2020 from: http://strangebeautiful.com/other-texts/kant-first-critique-cambridge.pdf.

Kant, I. (1784). Idea for a Universal History from a Cosmopolitan Point of View (Lewis White Beck, Trans.). From Immanuel Kant, "On History". New York: The Bobbs-Merrill Co. Retrieved March 31, 2020 from: https://www.marxists.org/reference/subject/ethics/kant/universal-history.htm. 
Kant, I. (1795). Toward Perpetual Peace (H. Reiss, Ed.). Cambridge: Cambridge nd University Press.

Kiss, A.-Ch. (1983). La nation de patrimoine commun de l'humanite. Recueil des Cour, 175, 99-256.

Kofanov, L. L. (Ed.). (2002). Digesty Yustiniana (Justinian Digest, in Russiam), Vol. 1. Moscow: Statut.

Larsen, S. (Ed.). (2004). Tragediya soobshchestv: obshchie resursy i individual'nyie interesy (The Tragedy of Communities: Shared Resources and Individual Interests, in Russian). In Teoriya I metody $v$ sotsyalnyh naukah (Theory and Methods in the Social Science) (pp. 206225). Moscow: MGIMO; ROSSPEN.

Lukashuk, I. I. (1997). Mezhdunarodnoe pravo. Osobiennaya chast' (International Law. Special part, in Russian). Moscow: BEK.

Marcuse, H. (1964). One-Dimensional Man. Studies in the Ideology of Advanced Industrial Society (D. Kellne, Ed.). London, New York: Routledge Classics. Retrieved March 31, 2020 from: https://ibcom.org/files/Marcuse, $\% 20 \mathrm{H} \% 20-\% 20$ OneDimensional \%20Man,\%202nd\%20edn.\%20(Routledge, \%202002).pdf.

Morozova, L. A. (1999). Antropologiya mirovoy pravovoy mysli. Yevropa $V-X V I I v v$ (Anthology of World Legal Thought. Europe V-XVII Centuries, in Russian), Vol. 2. Moscow: Mysl'.

OSCE. (2011). OSCE Human Dimension Commitments. Thematic Compilation, 1 ( $3^{\text {rd }}$ Ed.). Warsaw, Organization for Security and Co-operation in Europe. Retrieved March 31, 2020 from: https://www.osce.org/odihr/76894?download
$=$ true.

Prigogine, I., \& Stengers, I. (1986). Order out of Chaos: Man's New Dialogue with Nature. London: Fontana Press.

Prudchenko, Ye. V. (Ed.). (2007). Kopengagenski kriterii (Copenhagen criteria, in Russian). Dnipropetrovsk: Tsentr Yevropeyskoi informatsii. Retrieved March 31, 2020, from: http://ukrcei.org/uploads/files/default/kopengagenskie kriter ii.pdf.

Radzivill, O. A. (2017). Pravo narodiv vid neolitu do Novogo chasu (The right of peoples from the Neolithic to modern times, in Ukrainian), Vol. 1. Kyiv: NAU.

Radzivill, O., \& Pyvovar, Y. (2019). Philosophical and Legal Concepts in the Context of Regulating National and International Public Order. In I. Sopilko (Ed.), Jurisprudence in the Modern Information Space (pp. 40-54). Canada, Hamilton: Accent Graphics Communcations \& Publishing.

Radzivill, O., Pyvovar, Y., Sopilko, I., \& Pyvovar, I. (2018). Coordination of Fragmentation within the International Air Law. International Journal of Engineering \& Technology (UAE), 7(3.30), 280-283. http://dx.doi.org/10.14419/ijet.v7i3.30.18260.

Rao, K. (1981). Common Heritage of Mankind and the Moon Treaty. Indian Journal of International Law, 21(2), 275-278.

Reale, J., \& Anticery, D. (2003). Ot romantizma do nashih dnei. V Zapadnaia filosofia oy istokov do nashih dnei (From Romantisism to Present Day. In Western Philosophy from its Origins to the Present Day, in Russian), Vol. 4.Saint Pe- 
tersburg: Pnevma.

Rulan, N. (2000). Yuridicheskaya antropologiya (Legal Anthropology, in Russian). Moscow: Norma.

Shchiptsov, A. A., \& Iefremov, V. S. (1997). Osvoieniye Antarktiki (Exploration of the Antarctic, in Russian). In Antarktika: istoriya, sovremennost, perspektivy (Antarctica: History, Modernity, Prospects) (pp. 27-39). Kyiv: Naukova dumka.
Teilhard de Chardin, P. (1955). The phenomenon of man. New York: Harper Perennial Modern Classics.

Tuskoz, Zh. (1998). Mezhdunarodnoie pravo (International Law, in Russian). Kyiv: ArtEK.

United Nations (n.d.). Oceans and the Law of the Sea. Retrieved March 31, 2020, from: https://www.un.org/en/sections/issuesdepth/oceans-and-law-sea/index.html. 